\title{
PENGARUH PEMBERIAN ESTER STANOL TERHADAP KADAR KOLESTEROL LDL DAN HDL WANITA DISLIPIDEMIA
}

\author{
Novita Merdiana, Hesti Murwani $\mathbf{R}^{*}$ \\ Program Studi Ilmu Gizi Fakultas Kedokteran Universitas Diponegoro \\ Jl.Dr.Sutomo No.18, Semarang, Telp (024) 8453708, Email : gizifk@undip.ac.id
}

\begin{abstract}
Background : Dyslipidemia is one of risk factors associated with cardiovascular disease. Stanol esters are functional food which can decreased LDL cholesterol levels by inhibit cholesterol absorption in intestinal and can activate LDL receptor in cells surface.

Method : This research was quasi experimental study. Subject were dyslipidemic women with serum LDL cholesterol levels $\geq 130 \mathrm{mg} / \mathrm{dl}$ and $H D L$ cholesterol levels $<50 \mathrm{mg} / \mathrm{dl}$. They were classified into 2 groups, treatment group consuming 3,4 g stanol esters and control group consuming low fat milk for 2 weeks. Serum LDL cholesterol levels was measured with Friedewald equation and serum HDL cholesterol levels was measured with phosphotungstic precipitation method.

Result : Stanol esters have been shown to decreased LDL cholesterol levels up to 7,68\% and decreased HDL cholesterol levels 1,57\%, however both did not have a meaning statistically. Mean of LDL and HDL cholesterol before intervention on treatment group is 161,86 $\mathrm{mg} / \mathrm{dl}$ and 44,38 $\mathrm{mg} / \mathrm{dl}$. Mean of LDL and HDL cholesterol after intervention on treatment group is 148,63 $\mathrm{mg} / \mathrm{dl}$ and 43,54 $\mathrm{mg} / \mathrm{dl}$. Stanol esters did not affect LDL and HDL cholesterol levels significantly $(p>0,05)$.

Conclusion : Consumption 3,4 g of stanol esters had no effect on LDL and HDL cholesterol levels in women with dyslipidemia. There was no difference of LDL and HDL cholesterol levels between treatment and control groups.
\end{abstract}

\section{ABSTRAK}

Latar belakang : Dislipidemia merupakan salah satu faktor risiko terjadinya penyakit jantung dan pembuluh darah. Ester stanol merupakan pangan fungsional yang dapat menurunkan kadar kolesterol LDL dengan cara menghambat penyerapan kolesterol di usus halus dan mengaktifkan reseptor LDL di permukaan sel.

Metode : Jenis penelitian ini adalah quasi experimental. Subyek wanita dislipidemia dengan kadar kolesterol LDL $\geq$ $130 \mathrm{mg} / \mathrm{dl}$ dan $\mathrm{HDL}<50 \mathrm{mg} / \mathrm{dl}$. Subyek dibagi menjadi 2 kelompok, yaitu kelompok perlakuan yang diberikan ester stanol 3,4 g dalam susu rendah lemak dan kelompok kontrol yang diberikan susu rendah lemak saja selama 2 minggu. Metode pengukuran kadar kolesterol LDL menggunakan perhitungan Friedewald dan kadar kolesterol HDL menggunakan phosphotungstic precipitation.

Hasil : Ester stanol 3,4 g terbukti menurunkan kolesterol LDL sebesar 7,68\% dan terjadi penurunan kolesterol HDL sebesar 1,57\%, namun tidak bermakna secara statistik. Rerata kadar kolesterol LDL dan HDL sebelum penelitian kelompok perlakuan berturut-turut yaitu 161,86 mg/dl dan 44,38 mg/dl. Rerata kadar kolesterol LDL dan HDL sesudah penelitian kelompok perlakuan berturut-turut yaitu 148,63 mg/dl dan 43,54 mg/dl. Konsumsi ester stanol 3,4 g tidak berpengaruh secara bermakna terhadap kadar kolesterol LDL dan HDL $(p>0,05)$.

Kesimpulan : Konsumsi ester stanol 3,4 g/hari selama 2 minggu tidak memiliki pengaruh yang bermakna terhadap kadar kolesterol LDL dan HDL wanita dislipidemia. Tidak ada perbedaan yang bermakna kadar kolesterol LDL dan HDL antara kelompok perlakuan dan kontrol.

Kata kunci : ester stanol, kolesterol LDL, kolesterol HDL, dislipidemia

\section{PENDAHULUAN}

Dislipidemia merupakan kelainan
metabolisme lipid yang ditandai dengan peningkatan kadar kolesterol total, kolesterol Lowdensity Lipoprotein (LDL), trigliserida, dan penurunan kadar kolesterol High-density Lipoprotein (HDL). ${ }^{1}$ Kadar serum kolesterol LDL yang tinggi dan kolesterol HDL yang rendah berkaitan erat dengan salah satu penyebab utama terjadinya Penyakit Kardiovaskular (PKV). Penyakit Kardiovaskular yaitu salah satu penyakit yang menyebabkan morbiditas dan mortalitas di dunia terutama di negara berkembang. ${ }^{2}$

Pengaturan pola makan gizi seimbang dan olah raga rutin dapat menurunkan kadar kolesterol LDL dan meningkatkan kadar kolesterol HDL. ${ }^{3}$ Penanganan melalui konsumsi makanan yang belum banyak dikembangkan di Indonesia yaitu dengan mengonsumsi pangan fungsional berupa ester stanol. Ester stanol merupakan pangan fungsional yang dapat menurunkan kadar kolesterol LDL. ${ }^{4}$ Ester stanol merupakan bentuk esterifikasi dari stanol, dimana stanol dalam bentuk 
bebas tidak dapat terdispersi di dalam air maupun lemak. ${ }^{5}$ Stanol adalah hasil hidrogenasi sterol, sterol didapatkan dari distilasi minyak sayur atau minyak pinus. ${ }^{6}$

Ester stanol memiliki struktur, transporter, dan kelarutan yang sama dengan kolesterol, sehingga ester stanol dapat menurunkan kolesterol dengan cara berkompetisi dengan kolesterol dalam pembentukan misel saat proses absorpsi. Kolesterol yang tidak terserap oleh usus akan terbuang melalui feses. Kolesterol yang telah terserap akan dikeluarkan kembali ke lumen usus dengan protein transporter yaitu Adenosine triphosphate Binding Cassette (ABC). ${ }^{5,6}$ Di dalam usus halus penyerapan stanol berkisar antara $0,04-$ $0,2 \%{ }^{7,8}$ Ester stanol tidak disimpan dalam tubuh dan akan dibuang secara cepat melalui feses. ${ }^{9}$

Berdasarkan penelitian tahun 2002 mengenai pemberian ester stanol $2 \mathrm{~g}$ yang difortifikasikan dalam margarin selama 2 minggu dapat menurunkan kadar kolesterol LDL 10,2\%. ${ }^{9}$ Penelitian tahun 2005 di Korea menunjukkan bahwa pemberian 3,3 g ester stanol yang difortifikasikan ke dalam minuman yogurt selama 4 minggu dapat menurunkan kadar kolesterol LDL berkisar antara $6-10 \% .{ }^{10}$ Penelitian tahun 2002 dengan memberikan yogurt yang telah difortifikasi $3 \mathrm{~g}$ ester stanol selama 4 minggu dapat menurunkan kadar kolesterol LDL sebesar 13,7\%. ${ }^{11}$ Dosis optimal pemberian stanol yang dianjurkan oleh Foods and Drugs Administration (FDA) yaitu $2-3 \mathrm{~g}$ atau dalam bentuk ester yaitu sebesar 3,4 - 5,2 g., ${ }^{5,12}$ Ester stanol dapat menurunkan kadar kolesterol LDL dalam waktu 1 - 2 minggu, pada minggu ke-3 dan 4 kadar kolesterol LDL tidak mengalami penurunan atau dalam keadaan stabil. ${ }^{9,11}$

Produk minuman dengan fortifikasi ester stanol yang beredar di Indonesia adalah susu rendah lemak. Produk susu rendah lemak difortifikasi ester stanol sebesar 3,4 g/200 ml. Ester stanol lebih stabil pada produk berupa minuman rendah lemak seperti susu. ${ }^{12}$ Efektivitas produk tersebut belum terbukti secara ilmiah, oleh karena itu peneliti ingin membuktikan keefektifannya dalam menurunkan kadar kolesterol LDL dan meningkatkan kadar kolesterol HDL terhadap wanita dislipidemia.

\section{METODE}

Penelitian ini dilakukan pada bulan Agustus - Oktober 2013. Jenis penelitian yang digunakan yaitu quasi experimental. Variabel terikat penelitian ini adalah kadar kolesterol LDL dan HDL wanita dislipidemia, sedangkan variabel bebas digunakan yaitu ester stanol 3,4 g.

Subyek yang digunakan dalam penelitian ini antara lain yaitu karyawati kantor Dinas Pengelola Keuangan dan Aset Daerah (DPKAD) Semarang, SMA Negeri 1 Semarang, SMA Negeri 3 Semarang, dan SMA Negeri 5 Semarang dengan kriteria inklusi kadar kolesterol LDL $>130 \mathrm{mg} / \mathrm{dl}$ dan kadar kolesterol HDL $<50 \mathrm{mg} / \mathrm{dl}$, belum mengalami menopause, tidak sedang mengkonsumsi obat antihiperlipidemia dan tidak dalam keadaan sakit atau perawatan dokter, serta tidak dalam keadaan hamil atau menyusui.

Pengambilan sampel menggunakan metode consecutive sampling dan diperoleh subyek sebanyak 26 orang, kemudian dibagi menjadi 2 kelompok menggunakan simple random sampling, yang terdiri dari kelompok perlakuan yang diberikan ester stanol 3,4 g dalam susu rendah lemak $200 \mathrm{ml}$ dan kelompok kontrol yang diberikan plasebo berupa susu rendah lemak 200 $\mathrm{ml}$ saja. Intervensi dilakukan selama 2 minggu.

Kedua kelompok tidak diberikan pengaturan makan khusus atau tidak merubah pola makan subyek. Pencatatan asupan makan dilakukan sebelum dan selama intervensi berlangsung menggunakan formulir food recall 24 jam. Data asupan makan dianalisis menggunakan nutrisurvey dan kebutuhan energi total dihitung menggunakan rumus Mifflin, kemudian dibandingkan untuk mengetahui kecukupan asupan makan subyek. Pencatatan aktivitas fisik dilakukan sebanyak 3x selama penelitian. Pegelompokan kategori aktivitas atau beban kerja berdasarkan proporsi waktu kerja mengacu pada Physical Activity Levels (PAL). ${ }^{1}$ Pada hari ke-15 dilakukan pengambilan darah kembali untuk mengetahui perubahan kadar kolesterol LDL dan HDL. Kadar kolesterol LDL dan HDL dianalisis menggunakan perhitungan Friedewald dan phosphotungstic precipitation. $^{13,14}$

Perbedaan rerata kadar kolesterol LDL dan HDL sebelum dan sesudah intervensi diuji menggunakan paired t-test. Perbedaan rerata kadar kolesterol LDL dan HDL antara kedua kelompok dianalisis dengan menggunakan independent $t$-test.

\section{HASIL PENELITIAN \\ Karakterisktik Subyek}

Karakteristik subyek meliputi gambaran usia dan Indeks Massa Tubuh (IMT). 
Tabel 1. Gambaran Usia dan Indeks Massa Tubuh (IMT) Subyek

\begin{tabular}{|c|c|c|c|c|}
\hline \multirow{2}{*}{ Variabel } & \multicolumn{2}{|c|}{ Perlakuan $(n=13)$} & \multicolumn{2}{|c|}{ Kontrol $(n=13)$} \\
\hline & $\mathrm{n}$ & $\%$ & $\mathrm{n}$ & $\%$ \\
\hline \multicolumn{5}{|l|}{ Usia } \\
\hline $20-29$ & 1 & 7,7 & 1 & 7,7 \\
\hline $30-39$ & 2 & 15,4 & 2 & 15,4 \\
\hline $40-49$ & 7 & 53,8 & 6 & 46,2 \\
\hline $50-59$ & 3 & 23,1 & 4 & 30,8 \\
\hline \multicolumn{5}{|l|}{ IMT } \\
\hline Normal $(18,5$ - 22,9 kg/m²) & 2 & 15,4 & 1 & 7,7 \\
\hline $\begin{array}{l}\text { Overweight }(23,0-24,9 \\
\left.\mathrm{kg} / \mathrm{m}^{2}\right)\end{array}$ & 6 & 46,2 & 5 & 38,5 \\
\hline Obesitas I $\left(25-29,9 \mathrm{~kg} / \mathrm{m}^{2}\right)$ & 4 & 30,8 & 3 & 23,1 \\
\hline Obesitas II $\left(>30,0 \mathrm{~kg} / \mathrm{m}^{2}\right)$ & 1 & 7,7 & 4 & 30,8 \\
\hline
\end{tabular}

Tabel 1 menunjukkan bahwa sebagian sebagian besar memiliki IMT dengan kategori besar subyek berusia $40-49$ tahun $(50 \%)$ dan overweight $(42,3 \%)$ dan obesitas I (26,9\%).

Tabel 2. Keadaan subyek pada awal penelitian

\begin{tabular}{|c|c|c|c|c|}
\hline \multirow{2}{*}{\multicolumn{2}{|c|}{ Variabel }} & Perlakuan $(\mathrm{n}=$ & Kontrol $(n=13)$ & \multirow[t]{2}{*}{$\mathbf{p}^{\mathbf{a}}$} \\
\hline & & Mean \pm SD & Mean \pm SD & \\
\hline Usia (tahun) & & $43,71 \pm 8,16$ & $45,33 \pm 8,39$ & 0,622 \\
\hline IMT $\left(\mathrm{kg} / \mathrm{m}^{2}\right)$ & & $25,08 \pm 3,40$ & $27,28 \pm 3,82$ & 0,126 \\
\hline $\begin{array}{ll}\text { Kadar } & \text { Kolesterol } \\
(\mathbf{m g} / \mathbf{d l}) & \end{array}$ & LDL & $161,86 \pm 24,91$ & $164,30 \pm 29,63$ & 0,822 \\
\hline $\begin{array}{ll}\begin{array}{l}\text { Kadar } \\
\text { (mg/dl) }\end{array} & \text { Kolesterol } \\
\end{array}$ & HDL & $44,38 \pm 3,25$ & $42,46 \pm 6,23$ & 0,337 \\
\hline
\end{tabular}

Tabel 2 menunjukkan bahwa tidak terdapat perbedaan bermakna antara usia, IMT, kadar kolesterol LDL dan HDL antara kelompok perlakuan dan kontrol $(\mathrm{p}>0,05)$.

\section{Gambaran asupan makan subyek}

Asupan makan subyek yang didapatkan selama penelitian yaitu meliputi energi, karbohidrat, protein, lemak, serat, dan kolesterol.

Tabel 3. Gambaran Asupan Makan Subyek

\begin{tabular}{|c|c|c|c|}
\hline Asupan Zat Gizi & $\begin{array}{c}\text { Perlakuan }(\mathrm{n}=13) \\
\text { Mean } \pm \text { SD }\end{array}$ & $\begin{array}{c}\text { Kontrol }(\mathrm{n}=13) \\
\text { Mean } \pm \text { SD }\end{array}$ & $\mathbf{p}^{\mathbf{a}}$ \\
\hline \multicolumn{4}{|l|}{ Energi (kkal) } \\
\hline Pre & $1776,80 \pm 242,60$ & $1707,16 \pm 255,32$ & \multirow{4}{*}{0,410} \\
\hline Eksperimen & $1775,44 \pm 292,78$ & $1752,05 \pm 245,72$ & \\
\hline$\Delta$ & $-1,36 \pm 161,73$ & $44,89 \pm 115,67$ & \\
\hline $\mathbf{p}$ & $0,976^{\mathrm{c}}$ & $0,152^{\mathrm{c}}$ & \\
\hline \multicolumn{4}{|l|}{ Karbohidrat (g) } \\
\hline Pre & $217,58 \pm 50,39$ & $245,72 \pm 70,84$ & \multirow{4}{*}{0,765} \\
\hline Eksperimen & $216,06 \pm 40,38$ & $237,88 \pm 36,73$ & \\
\hline$\Delta$ & $-1,52 \pm 47,74$ & $-7,85 \pm 58,21$ & \\
\hline $\mathbf{p}$ & $0,967^{\mathrm{b}}$ & $0,977^{\mathrm{b}}$ & \\
\hline \multicolumn{4}{|l|}{ Protein (g) } \\
\hline Pre & $71,95 \pm 19,35$ & $61,59 \pm 12,58$ & \\
\hline Eksperimen & $67,04 \pm 12,24$ & $60,51 \pm 13,02$ & \\
\hline$\Delta$ & $-4,91 \pm 13,47$ & $-1,08 \pm 10,82$ & 0,433 \\
\hline
\end{tabular}




\begin{tabular}{lccc}
$\mathbf{p}$ & $0,214^{\mathrm{b}}$ & $0,724^{\mathrm{b}}$ & \\
\hline Lemak (g) & & & \\
$\mathbf{P r e}$ & $73,45 \pm 22,82$ & $61,87 \pm 16,53$ & \\
Eksperimen & $75,55 \pm 18,11$ & $60,43 \pm 9,71$ & \\
$\mathbf{\Delta}$ & $2,11 \pm 18,31$ & $-1,44 \pm 18,77$ & 0,630 \\
$\mathbf{p}$ & $0,685^{\mathrm{b}}$ & $0,787^{\mathrm{b}}$ & \\
\hline Serat (g) & & & \\
$\mathbf{P r e}$ & $11,39 \pm 3,77$ & $12,27 \pm 5,43$ & \\
$\mathbf{E k s p e r i m e n}$ & $10,51 \pm 3,10$ & $11,51 \pm 4,00$ & \\
$\boldsymbol{\Delta}$ & $-0,88 \pm 5,00$ & $-0,75 \pm 6,18$ & 0,953 \\
$\mathbf{p}$ & $0,536^{\mathrm{b}}$ & $0,668^{\mathrm{b}}$ & \\
\hline Kolesterol (mg) & & & \\
$\mathbf{P r e}$ & $348,44 \pm 152,96$ & $255,85 \pm 89,80$ & \\
$\mathbf{E k s p e r i m e n}$ & $325,02 \pm 171,80$ & $232,32 \pm 70,01$ & \\
$\boldsymbol{\Delta}$ & $-23,41 \pm 96,81$ & $-23,52 \pm 109,97$ & 0,998 \\
$\mathbf{p}$ & $0,344^{\mathrm{b}}$ & $0,586^{\mathrm{b}}$ & \\
\hline
\end{tabular}

Independent t-test ${ }^{\mathrm{b}}$ Paired t-test ${ }^{c}$ Wilcoxon

Tabel 3 menunjukkan tidak terdapat subyek berpartisipasi dalam penelitian. Rerata perbedaan rerata asupan energi, protein lemak, perubahan asupan zat gizi menunjukkan tidak ada karbohidrat, kolesterol dan serat sebelum dan perbedaan antara kelompok perlakuan dan kontrol selama intervensi pada kedua kelompok $(\mathrm{p}>0,05) . \quad(\mathrm{p}>0,05)$. Terdapat perbedaan rerata asupan Hal ini menunjukkan bahwa seluruh subyek tidak lemak selama penelitian antara kelompok mengubah asupan makan secara sengaja karena perlakuan dan kontrol.

Tabel 4. Kecukupan Asupan Makan Subyek

\begin{tabular}{|c|c|c|c|c|c|c|}
\hline \multirow{3}{*}{ Asupan } & \multicolumn{3}{|c|}{ Perlakuan $(n=13)$} & \multicolumn{3}{|c|}{ Kontrol $(n=13)$} \\
\hline & Hasil Analisis & Kebutuhan & \multirow[b]{2}{*}{$\mathbf{p}$} & Hasil Analisis & Kebutuhan & \multirow[b]{2}{*}{$\mathbf{p}$} \\
\hline & \multicolumn{2}{|c|}{ Mean \pm SD } & & \multicolumn{2}{|c|}{ Mean \pm SD } & \\
\hline \multicolumn{7}{|l|}{$\begin{array}{l}\text { Energi } \\
\text { (kkal) }\end{array}$} \\
\hline Pre & $\begin{array}{c}1776,80 \pm 242,6 \\
0\end{array}$ & $1707,83 \pm 141,7$ & $\begin{array}{l}0,367 \\
\text { a }\end{array}$ & $\begin{array}{c}1707,16 \pm 255,3 \\
2\end{array}$ & $1642,34 \pm 142,4$ & $0,357^{\mathrm{a}}$ \\
\hline $\begin{array}{l}\text { Eksperime } \\
\text { n }\end{array}$ & $\begin{array}{c}1775,44 \pm 292,7 \\
8\end{array}$ & 1 & $\begin{array}{l}0,440 \\
\text { a }\end{array}$ & $\begin{array}{c}1752,05 \pm 245,7 \\
2\end{array}$ & 6 & $\underset{\mathrm{b}}{0,101}$ \\
\hline \multicolumn{7}{|l|}{$\begin{array}{l}\text { Karbohidrat } \\
\text { (g) }\end{array}$} \\
\hline Pre & $217,58 \pm 50,39$ & & $\underset{\mathrm{a}}{0,004}$ & $245,72 \pm 70,84$ & & $0,617^{\mathrm{a}}$ \\
\hline $\begin{array}{l}\text { Eksperime } \\
\text { n }\end{array}$ & $216,06 \pm 40,38$ & $256,17 \pm 21,26$ & $\begin{array}{l}0,006 \\
\text { a }\end{array}$ & $237,88 \pm 36,73$ & $246,35 \pm 21,38$ & $0,392^{\mathrm{a}}$ \\
\hline \multicolumn{7}{|l|}{$\begin{array}{l}\text { Protein } \\
\text { (g) }\end{array}$} \\
\hline Pre & $71,95 \pm 19,35$ & & $\underset{\mathrm{a}}{0,190}$ & $61,59 \pm 12,58$ & & $0,999^{\mathrm{a}}$ \\
\hline $\begin{array}{l}\text { Eksperime } \\
\mathbf{n}\end{array}$ & $67,04 \pm 12,24$ & $64,04 \pm 5,31$ & $\begin{array}{l}0,469 \\
\mathrm{a}\end{array}$ & $60,51 \pm 13,02$ & $61,58 \pm 5,34$ & $0,793^{\mathrm{a}}$ \\
\hline \multicolumn{7}{|l|}{$\begin{array}{l}\text { Lemak } \\
\text { (g) }\end{array}$} \\
\hline Pre & $73,45 \pm 22,82$ & $47,44 \pm 3,93$ & $\underset{\mathrm{a}}{0,002}$ & $61,87 \pm 16,53$ & $45,62 \pm 3,95$ & $0,006^{\mathrm{a}}$ \\
\hline Eksperime & $75,55 \pm 18,11$ & & 0,000 & $60,43 \pm 9,71$ & & $0,000^{\mathrm{a}}$ \\
\hline
\end{tabular}




\begin{tabular}{|c|c|c|c|c|c|c|}
\hline \multicolumn{7}{|l|}{$\begin{array}{l}\text { Serat } \\
(\mathrm{g})\end{array}$} \\
\hline Pre & $11,39 \pm 3,77$ & \multirow[b]{2}{*}{$25-35$} & & $12,27 \pm 5,43$ & \multirow[b]{2}{*}{$25-35$} & \\
\hline $\begin{array}{l}\text { Eksperime } \\
\text { n }\end{array}$ & $10,51 \pm 3,10$ & & - & $11,51 \pm 4,00$ & & - \\
\hline \multicolumn{7}{|l|}{$\begin{array}{l}\text { Kolesterol } \\
\text { (mg) }\end{array}$} \\
\hline Pre & $348,44 \pm 152,96$ & \multirow[b]{2}{*}{$<200$} & & $255,85 \pm 89,80$ & \multirow[b]{2}{*}{$<200$} & \\
\hline $\begin{array}{l}\text { Eksperime } \\
\text { n }\end{array}$ & $325,02 \pm 171,80$ & & - & $232,32 \pm 70,01$ & & - \\
\hline
\end{tabular}

Tabel 4 menunjukkan bahwa tidak terdapat perbedaan bermakna antara hasil analisis asupan dengan rerata kebutuhan asupan energi serta protein selama dan sebelum penelitian baik kelompok perlakuan maupun kontrol. Terdapat perbedaan bermakna antara hasil analisis asupan dengan rerata kebutuhan asupan karbohidrat selama dan sebelum penelitian pada kelompok perlakuan saja. Terdapat perbedaan bermakna antara hasil analisis asupan dengan rerata kebutuhan asupan lemak sebelum penelitian baik kelompok perlakuan maupun kontrol. Rerata asupan serat sebelum dan selama penelitian pada kedua kelompok tidak mencukupi kebutuhan. Rerata asupan kolesterol sebelum dan sesudah penelitian baik kelompok perlakuan dan kelompok kontrol lebih dari batas anjuran (200 mg).

\section{Aktivitas fisik subyek}

\begin{tabular}{|c|c|c|}
\hline \multirow[t]{2}{*}{ Kelompok } & \multirow[t]{2}{*}{$\mathbf{N}$} & $\begin{array}{c}\begin{array}{c}\text { Energy Out } \\
\text { (kkal) }\end{array} \\
\end{array}$ \\
\hline & & Mean \pm SD \\
\hline Perlakuan & 13 & $566,45 \pm 84,17$ \\
\hline Kontrol & 13 & $589,33 \pm 119,19$ \\
\hline $\mathbf{p}^{\mathrm{a}}$ & & 0,577 \\
\hline
\end{tabular}

Tabel 5 menunjukkan bahwa rerata pengeluaran energi yang digunakan untuk aktivitas fisik antara kelompok perlakuan dan kontrol tidak terdapat perbedaan yang bermakna $(\mathrm{p}>0,05)$.

\section{Pengaruh ester stanol terhadap kadar} kolesterol LDL dan HDL

Tabel 6. Pengaruh ester stanol terhadap kadar kolesterol LDL

\begin{tabular}{lcccccc}
\hline \multirow{2}{*}{ Kelompok } & $\mathbf{N}$ & $\begin{array}{c}\text { Awal } \\
(\mathbf{m g} / \mathbf{d l})\end{array}$ & $\begin{array}{c}\text { Akhir } \\
(\mathbf{m g} / \mathbf{d l})\end{array}$ & $\begin{array}{c}\boldsymbol{\Delta} \\
(\mathbf{m g} / \mathbf{d l})\end{array}$ & \multirow{2}{*}{$\%$} & \multirow{2}{*}{$\mathbf{p}^{\mathbf{a}}$} \\
\cline { 3 - 5 } & & $\mathbf{M e a n} \pm \mathbf{S D}$ & $\mathbf{M e a n} \pm \mathbf{S D}$ & $\mathbf{M e a n} \pm \mathbf{S D}$ & & \\
\hline Perlakuan & 13 & $161,86 \pm 24,91$ & $148,63 \pm 29,90$ & - & 7,68 & 0,079 \\
& & & & $13,23 \pm 24,89$ & & \\
Kontrol & 13 & $164,30 \pm 29,64$ & $157,83 \pm 24,13$ & $-6,47 \pm 23,45$ & 2,86 & 0,340 \\
\hline
\end{tabular}

Tabel 6 menunjukkan bahwa kelompok perlakuan dan kontrol mengalami penurunan kadar kolesterol LDL sebesar 7,68\% dan 2,86\%. Namun, secara statistik penurunan kadar kolesterol LDL pada kedua kelompok tidak beda bermakna $(p<0,05)$. 
Tabel 7. Pengaruh ester stanol terhadap kadar kolesterol HDL

\begin{tabular}{lcccccc}
\hline \multirow{2}{*}{ Kelompok } & $\mathbf{N}$ & $\begin{array}{c}\text { Awal } \\
(\mathbf{m g} / \mathbf{d l})\end{array}$ & $\begin{array}{c}\text { Akhir } \\
(\mathbf{m g} / \mathbf{d l})\end{array}$ & $\begin{array}{c}\boldsymbol{\Delta} \\
(\mathbf{m g} / \mathbf{d l})\end{array}$ & \multirow{2}{*}{$\boldsymbol{\Delta} \%$} & \multirow{2}{*}{$\mathbf{p}^{\mathbf{a}}$} \\
\cline { 2 - 5 } & & $\mathbf{M e a n} \pm \mathbf{S D}$ & $\mathbf{M e a n} \pm \mathbf{S D}$ & $\mathbf{M e a n} \pm \mathbf{S D}$ & & \\
\hline Perlakuan & 13 & $44,38 \pm 3,25$ & $43,54 \pm 6,42$ & $-0,85 \pm 6,71$ & 1,57 & 0,657 \\
Kontrol & 13 & $42,46 \pm 6,23$ & $40,92 \pm 5,19$ & $-1,54 \pm 6,59$ & 2,06 & 0,416 \\
\hline
\end{tabular}

Tabel 7 menunjukkan bahwa kadar kolesterol HDL pada kedua kelompok tidak mengalami peningkatan. Penurunan lebih besar terjadi pada kelompok kontrol yaitu $-1,54 \pm 6,59 \mathrm{mg} / \mathrm{dl}$. Kadar kolesterol HDL kedua kelompok tidak beda bermakna baik sebelum maupun sesudah

Tabel 8. Perbedaan rerata perubahan kadar kolesterol LDL dan HDL

\begin{tabular}{cccc}
\hline $\boldsymbol{\Delta}(\mathbf{m g} / \mathbf{d l})$ & Perlakuan & Kontrol & $\mathbf{p}$ \\
\hline Kolesterol LDL & $-13,23 \pm 24,89$ & $-6,47 \pm 23,45$ & $0,249^{\mathrm{a}}$ \\
Kolesterol HDL & $-0,85 \pm 6,71$ & $-1,54 \pm 6,59$ & $0,793^{\mathrm{b}}$ \\
\hline
\end{tabular}

${ }^{\mathrm{a}}$ Mann Whitney ${ }^{\mathrm{b}}$ Independent $t$-test

Tabel 8 menunjukkan bahwa rerata perubahan kadar kolesterol LDL dan HDL tidak terdapat perbedaan bermakna baik kelompok perlakuan maupun kontrol $(\mathrm{p}>0,05)$.

\section{PEMBAHASAN}

\section{Pengaruh ester stanol terhadap kadar} kolesterol LDL

Berdasarkan hasil analisis statistik penurunan kadar kolesterol LDL kelompok perlakuan tidak bermakna. Namun, berdasarkan angka pengukuran terjadi penurunan sebesar $7,68 \%$. Rerata perubahan kadar kolesterol LDL antara kelompok perlakuan dan kontrol tidak menunjukkan perbedaan yang bermakna. Penurunan kadar kolesterol LDL pada kelompok perlakuan sebesar $-13,23 \pm 24,89 \mathrm{mg} / \mathrm{dl}$ dan kelompok kontrol sebesar $-6,47 \pm 23,45 \mathrm{mg} / \mathrm{dl}$. Beberapa hal yang dapat mempengaruhi kadar kolesterol LDL selain ester stanol dalam penelitian ini yaitu asupan makanan.

Ester stanol merupakan salah satu contoh pangan fungsional yang dapat mengurangi kolesterol LDL dengan cara menghambat absorpsi kolesterol dan meningkatkan reseptor LDL di hepar. ${ }^{7}$ Ester stanol mempunyai bentuk struktur yang menyerupai kolesterol. ${ }^{11,15}$ Ester stanol akan berkompetisi dengan kolesterol dalam pembentukan misel di lumen usus halus. ${ }^{16}$ Ester stanol dan kolesterol yang tergabung dalam misel akan diabsorpsi menggunakan protein transporter Niemann-Pick C1-like 1 (NPC1L1). Saat berada di dalam enterosit, ester stanol dan kolesterol akan menurunkan regulasi Sterol Regulatory Element
Binding Protein-2 (SREBP-2) yang akan menghambat regulasi Sterol Regulatory Element (SRE) dan HMG-CoA reduktase sehingga dapat membatasi biosintesis kolesterol. Ester stanol dan kolesterol berinteraksi dengan Liver X Receptor (LXR), kemudian mengaktifkan protein-protein transporter yang berada dipermukaan enterosit bernama Adenosine triphosphate Binding Cassette $(\mathrm{ABC})$. Protein transporter akan mengembalikan kolesterol dari enterosit ke lumen usus, sehingga kolesterol tidak akan bergabung dalam misel dan ekskresi kolesterol melalui feses akan meningkat. ${ }^{5,17}$ Ester stanol dan kolesterol yang telah terserap oleh usus, akan dibawa oleh kilomikron menuju hepar. ${ }^{16}$

Kolesterol yang terabsorpsi oleh usus akan berkurang akibat berkompetisi dengan ester stanol, sehingga akan terjadi rangsangan timbal balik negatif (negative feedback mechanism) pada regulasi HMGKoA reduktase untuk mensistesis kolesterol lebih banyak dari asetil-KoA di dalam hepar. ${ }^{5,18}$ Kolesterol yang disintesis oleh hepar disekresikan dalam VLDL. Di dalam sirkulasi VLDL akan berubah menjadi IDL dengan berkurangnya trigliserid yang dibawa dan kemudian menjadi LDL yang kaya akan kolesterol. $^{7,16}$

Ester stanol juga dapat meningkatkan ekspresi reseptor LDL yang terdapat di hepatosit. Reseptor LDL akan menangkap LDL yang berada di sirkulasi untuk didegradasi. Selain menangkap LDL, reseptor LDL juga akan menangkap IDL sehingga pembentukan LDL akan berkurang dan 
kadar kolesterol LDL dalam serum akan menurun. ${ }^{7,19}$

Asupan lemak pada awal penelitian yaitu $73,45 \pm 22,82 \mathrm{~g}$ dan selama penelitian naik menjadi $75,55 \pm 18,11 \mathrm{~g}$, sedangkan kebutuhan lemak kelompok perlakuan sebesar 47,44 $\pm 3,93 \mathrm{~g}$, sehingga dapat disimpulkan asupan lemak berlebihan. Asupan lemak selama penelitian kelompok perlakuan dan kontrol terdapat perbedaan yang bermakna. Pada kelompok perlakuan $(75,55 \pm 18,11 \mathrm{~g})$ lebih besar dibanding kelompok kontrol $(60,43 \pm 9,71 \mathrm{~g})$. Asupan lemak yang berlebih berdampak pada distribusi lemak yang abnormal, sehingga terjadi obesitas. Obesitas dapat menyebabkan gangguan regulasi asam lemak yang memicu peningkatan trigliserida dan ester kolesterol. Peningkatan trigliserida akan meningkatkan produksi VLDL dan disekresikan ke sirkulasi kemudian berubah menjadi LDL. ${ }^{20}$ Meningkatnya LDL di sirkulasi dan terbatasnya ekspresi reseptor LDL oleh ester stanol di permukaan hepatosit menyebabkan penangkapan LDL oleh reseptor LDL tidak maksimal, sehingga LDL yang berada di sirkulasi tidak dapat berkurang.

Rerata asupan serat sebelum dan selama penelitian yaitu $10,51 \pm 3,10$ dan $11,39 \pm 3,77 \mathrm{~g}$. Konsumsi serat yang dianjurkan sebanyak 25-35 gr/hari, sehingga asupan serat seluruh subyek masih kurang. Serat dapat membantu ester stanol dalam menurunkan kadar kolesterol dengan cara mengikat asam empedu dan kolesterol untuk diekskresikan melalui feses, sehingga kolesterol yang terabsorpsi dan asam empedu yang kembali ke hepar akan berkurang. Hal tersebut menyebabkan persediaan kolesterol di hepar akan menurun. Berkurangnya asam empedu yang kembali ke hepar memicu produksi asam empedu baru dari kolesterol. Serat juga dapat menghambat sintesis kolesterol dengan melalui proses fermentasi serat oleh bakteria yang ada di kolon, sehingga menghasilkan propionat, asetat, dan butirat yang akan menghambat sintesis kolesterol. ${ }^{1,21}$ Namun asupan serat subyek penelitian masih kurang dari anjuran sehigga tidak dapat membantu ester stanol dalam menurunkan kadar kolesterol LDL secara bermakna.

Asupan kolesterol pada awal penelitian yaitu $348,44 \pm 152,96 \mathrm{mg}$ dan selama penelitian turun menjadi $325,02 \pm 171,80 \mathrm{mg}$, sedangkan rekomendasi Terapeutic Life style Changes (TLC) untuk asupan kolesterol dalam sehari yaitu $\leq 200$ mg. ${ }^{22}$ Asupan kolesterol pada kelompok perlakuan baik sebelum maupun selama penelitian lebih besar daripada kelompok kontrol. Konsumsi kolesterol yang melebihi kebutuhan mengakibatkan kerja ester stanol 3,4 g dalam menghambat kolesterol saat pembentukan misel tidak efektif, sehingga kolesterol yang terabsorpsi masih banyak.

\section{Pengaruh ester stanol terhadap kadar kolesterol HDL}

Ester stanol tidak berpengaruh terhadap peningkatan HDL, dengan bukti hasil penelitian menunjukkan penurunan kadar kolesterol HDL pada kelompok perlakuan sebesar $-0,85 \pm 6,71$ mg/dl. Kadar kolesterol HDL pada kelompok kontrol terjadi penurunan yang lebih besar yaitu $1,54 \pm 6,59 \mathrm{mg} / \mathrm{dl}$ namun tidak bermakna secara statistik. Rerata perubahan kadar kolesterol HDL antara kelompok perlakuan dan kontrol tidak terdapat perbedaan bermakna.

Peningkatan aktivitas fisik berkaitan dengan pembentukan pre $\beta$-HDL lebih banyak, sehingga dapat membantu ester stanol dalam meningkatkan kadar kolesterol HDL. Ester stanol akan mengaktifkan protein transporter bernama Adenosine triphosphate Binding Cassette-Al (ABCA1). ABCA1 akan bertugas mengeluarkan kolesterol bebas dari sel perifer menuju sirkulasi dan bergabung dalam pre $\beta$-HDL kemudian dibawa menuju hepar. ${ }^{23}$

Energi yang dikeluarkan untuk aktivitas fisik paling sedikit $600 \mathrm{kkal}$ dapat mencegah terjadinya PKV dengan meningkatnya kadar kolesterol HDL. ${ }^{24}$ Rerata pengeluaran energi yang digunakan untuk aktivitas fisik pada subyek kelompok perlakuan dan kontrol yaitu 566,4 dan 589,3 kkal. Hal tersebut menunjukkan bahwa subyek kurang aktif, sehingga pengeluaran energi yang kurang dapat berdampak pada obesitas. Kondisi obesitas akan menurunkan kadar kolesterol HDL dengan terjadinya peningkatan katabolisme HDL dan apolipoprotein A- $1 .{ }^{25}$

\section{SIMPULAN}

Pemberian ester stanol 3,4 g/hari selama 2 minggu tidak memberikan pengaruh yang bermakna terhadap kadar kolesterol LDL dan HDL. Tidak ada perbedaan perubahan kadar kolesterol LDL dan HDL antara kedua kelompok.

\section{SARAN}

Ester stanol 3,4g dapat dikonsumsi oleh penderita dislipidemia dengan disertai pengendalian asupan lemak, serat, dan kolesterol serta aktivitas fisik supaya dapat menurunkan kadar kolesterol LDL dan meningkatkan kadar kolesterol HDL secara efektif. 


\section{DAFTAR PUSTAKA}

1. Krummel DA. Medical Nutrition Therapy for Cardiovascular Disease. In: L. Kathleen M, Sylvia ES, editors. Krause's Food and Nutrition Therapy. $13^{\text {th }}$ edition. Philadelphia, USA - Saunders Elsevier; 2012. p. 742 - 758.

2. Sanchez-Muniz FJ. Dietary fibre and cardiovascular health. Nutr Hosp. 2012; 27: $31-$ 45.

3. Fletcher B, Berra K, Ades P, Braun LT, Burke LE, Durstine JL, et al. Managing abnormal blood lipids, a collaborative approach. Circulation. 2005; 112: 3184 - 3209 .

4. Jong AD, Plat J, Bast A, Godschalk RWL, Basu S, Mensink RP. Effects of plant sterol and stanol ester consumption on lipid metabolism, antioxidant status and markers of oxidative stress, endothelial function and low-grade inflammation in patients on current statin treatment. European Journal of Clinical Nutrition. 2008; 62: 263 - 273.

5. Kamal-Eldin A, Moazzami A. Plant Sterols and Stanols as Cholesterol-Lowering Ingredients in Functional Foods. Recent Patents on Food, Nutrition \& Agriculture. 2009; 1: 1 - 14.

6. Acuff RV, Cai DJ, Dong ZP, Bell D. The lipid lowering effect of plant sterol ester capsules in hypercholesterolemic subjects. BioMed Central. Lipid in Health and Disease. 2007; 6: 11.

7. Jong AD, Plat J , Mensink RP. Metabolic effects of plant sterols and stanols (Review). Journal of Nutritional Biochemistry. 2003; 14: 362 - 369.

8. Laitinen K, Gylling H. Dose-dependent LDLcholesterol lowering effect by plant stanol ester consumption: clinical evidence. BioMed Central. Lipid in Health and Disease. 2012; 11: 140.

9. Hallikainen M, Sarkkinen E, Wester I, Uusitupa M. Short-term LDL cholesterol-lowering efficacy of plant stanol esters. BioMed Central. Cardiovascular Disorders. 2002; 2: 14.

10. Yae JH, Oh YK, Joo BK, Ho JL, Yangsoo J, Liponkoski L, et al. Plant stanol esters in low-fat yogurt reduces total and low-density lipoprotein cholesterol and low-density lipoprotein oxidation in normocholesterolemic and mildly hypercholesterolemic subjects. Nutrition Research Elsevier. 2005; 25: 743 - 753.

11. Mensink RP, Ebbing S, Lindhout M, Plat J, Hougten MMA. Effects of plant stanol esters supplied in low-fat yogurt on serum lipids and lipoprotein, non-cholesterol sterols and fat soluble antioxidant concentrations. Elsevier Science Ireland. 2002; 160: 205 - 213.

12. Cantrill R, Kawamura Y. Phytosterols, phytostanol and their esters. Chemical and Technical Assesment. 2008; 1 - 13 .

13. Assmann G, Schriewer H, Schmitz G, Edgar-Otto H. Quantification of High-Density-Lipoprotein Cholesterol by Precipitation with Phosphotungstic
Acid/ $\mathrm{MgCl}_{2}$. Clinical Chemistry. 1983; 29(12): $2026-2030$.

14. Widiastuti E. Perbedaan Kadar LDL-Kolesterol Metoda Direk dengan Formulasi Friedewald. Patologi Klinik FK Undip. 2003.

15. Lichtenstein AH, Deckelbaum RJ. Stanol/sterol ester - containing foods and blood cholesterol levels. American Heart Association Inc. Circulation. 2001; 103: 1177 - 1179.

16. Mensink RP, Plat J. Plant Stanol and Sterol Esters in the Control of Blood Cholesterol Levels: Mechanism and Safety Aspects. Am J Cardiol. 2005; 96: p.15D - 22D.

17. Salo P, Wester I. Low-fat Formulations of Plant Stanols and Sterols. Elsevier Inc. Am J Cardiol. 2005; 96(suppl): 51D - 54D.

18. Janice LT, Melinda MM, Linda AV. The Science of Nutrition. 2011; p. $175-180$.

19. Mensink RP, Plat J. Effect of plant stanol esters on LDL receptor protein expression and on LDL receptor and HMIG-CoA reductase mRNA expression in mononuclear blood cells of healthy men and women. The FASEB journal. 2002; Vol.16: 258 - 260 .

20. Misra A, Luthra K, Vikram NK. Dyslipidemia in Asian Indians: Determinants and Significance. JAPI. 2004; 52: 137 - 142 .

21. Gropper SS, Smith JL, Groff JL. Advanced Nutrition and Human Metabolism. 5th ed. United States of America: Wadsworth; 2009. p. 131 177.

22. Whitney E, Rolfes SR. Understanding Nutritional. $11^{\text {th }}$ edition. United States, Thomson Wadsworth; 2008.

23. Fredenrich A, Bayer P. Reverse cholesterol transport, high density lipoprotein and HDL cholesterol: recent data. Diabetes Metab. 2003; 29: $201-205$.

24. Mora S, Cook N, Buring JE, Ridker PM, Lee IM. Physical Activity and Reduced Risk of Cardiovascular Events: Potential Mediating Mechanism. Circulation. American Heart Association. 2007; 116: 2110 - 2118.

25. Genest J, Rashid S. Effect of Obesity on Highdensity Lipoprotein Metabolism. Obesity. 2007; 15(12): $2875-2888$. 